\title{
Postoperative delirium: risk factors and management: Continuing Professional Development
}

\author{
Alan J. Chaput, PharmD, MD · Gregory L. Bryson, MD
}

Received: 11 October 2011/Accepted: 16 December 2011/Published online: 4 February 2012

(c) Canadian Anesthesiologists' Society 2012

\begin{abstract}
Purpose Postoperative delirium often remains undiagnosed and therefore untreated. The purpose of this continuing professional development module is to identify patients at high risk of developing delirium following noncardiac surgery and to provide tools to aid in the diagnosis of delirium at the bedside. Optimal prevention and treatment strategies are recommended.

Principal findings Delirium is characterized by an acute onset and a fluctuating course, inattention, disorganized thinking and an altered level of consciousness, and occurs in up to $40 \%$ of patients in the perioperative period. The pathophysiology of delirium is multifactorial, but it is believed to be related to inflammation, altered neurotransmission, and stress in the patient who has had surgery. Acetylcholine and dopamine appear to play a significant role. There is an increased risk of a poor outcome in patients who develop delirium, including a longer hospital stay and death. Surgical and patient factors play a significant role in predicting who will subsequently develop delirium. Prevention is much more effective than treatment in the management of delirium. The most effective prevention strategies include proactive geriatric assessment and care of the patient on a geriatrics surgical ward as well as prophylactic low-dose antipsychotic agents. From an anesthetic perspective, evidence in some surgical populations would support the use of regional techniques and minimal sedation. If delirium develops, treatment with lowdose oral antipsychotics appears to be most effective.
\end{abstract}

\footnotetext{
A. J. Chaput, PharmD, MD ( $₫)$. G. L. Bryson, MD Department of Anesthesiology, The Ottawa Hospital, University of Ottawa, 249C-1053 Carling Avenue, Suite B310, Ottawa, ON K1Y4E9, Canada

e-mail: achaput@ottawahospital.on.ca
}

Conclusions Delirium is a serious condition that must be recognized early and treated promptly to minimize deleterious outcomes. In order to institute prevention strategies and treat the condition effectively when it occurs, the anesthesiologist must be vigilant in identifying patients at risk and in screening for this condition.

\section{Objectives of this Continuing Professional Development (CPD) module:}

After reading this module, the reader should be able to:

1. Define delirium in the context of other cognitive changes following non-cardiac surgery.

2. Understand the incidence and adverse outcomes associated with delirium.

3. List predisposing and precipitating factors of postoperative delirium and identify the patient at risk.

4. Explain the underlying pathophysiologic mechanisms believed to be implicated in causing delirium.

5. Formulate an anesthetic plan that minimizes the risk of developing postoperative delirium.

6. Devise a management plan to treat postoperative delirium most effectively while minimizing the adverse effects of treatment.

Like other Western nations, Canada's population is aging rapidly. Over the past 50 years, the proportion of Canadians over the age of 65 has risen from $7.7 \%$ to $13.7 \%$. $^{\text {A }}$ Statistics Canada estimates that the proportion of seniors will double

\footnotetext{
A http://www12.statcan.ca/census-recensement/2006/as-sa/97-551/ table/t1-eng.cfm (accessed September 2011).
} 
yet again by 2036 and will represent $23-25 \%$ of Canada's population. $^{\mathrm{B}}$ This rapid demographic shift will impact anesthesiologists and hospitals directly as it is estimated that one in three persons over the age of 65 will undergo an anesthetic procedure in any given year. ${ }^{1}$ Regrettably, many of these surgical encounters will be complicated by disorders of cognitive function.

Delirium is a transient fluctuating disturbance of consciousness, attention, cognition, and perception. ${ }^{2}$ While delirium may occur in patients of any age, it is a particularly common complication of anesthesia and surgery in the elderly. Recent estimates suggest that treatment of delirium adds US $\$ 2,500$ to the cost of hospital stays for patients over the age of 65 , costing Medicare approximately US $\$ 6.9$ billion annually. ${ }^{3}$ In this context, the prevention and treatment of delirium must be viewed as a priority for patients, physicians, and hospitals alike. This module will help perioperative physicians identify patients at risk for delirium and offer strategies for its prevention and treatment. While the topic has been reviewed recently, ${ }^{4}$ the focus of this article is geared more specifically toward pathophysiology, incidence and outcomes, and specific perioperative interventions that have been shown to prevent postoperative delirium.

\section{Definition}

In the Diagnostic and Statistical Manual of Mental Disorders (DSM-IV), delirium in both surgical and medical patients is defined by three criteria: ${ }^{2}$ "A) Disturbance of consciousness (i.e., reduced clarity of awareness of the environment) with reduced ability to focus, sustain, or shift attention; B) A change in cognition (such as memory deficit, disorientation, language disturbance) or the development of a perceptual disturbance; and C) The disturbance develops over a short period of time (usually hours to days) and tends to fluctuate during the course of the day. "While many clinicians associate delirium with hyperactive behaviour (e.g., restlessness, pulling out lines, striking out), hypoactive and mixed motor subtypes are also described. ${ }^{5}$ Hypoactive delirium characterized by "...decreased alertness, sparse or slow speech, lethargy, slow movements, staring, and apathy" 5 may be present in over $40 \%$ of delirious older patients. ${ }^{6}$

One must distinguish delirium from other cognitive disorders, ${ }^{7}$ such as dementia, postoperative cognitive dysfunction (POCD), and emergence delirium. The DSM-IV defines dementia as "multiple cognitive deficits that include memory impairment and at least one of the

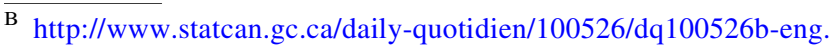
htm (accessed September 2011).
}

following cognitive disturbances: aphasia, apraxia, agnosia, or a disturbance in executive functioning. The cognitive deficits must be sufficiently severe to cause impairment in occupational or social functioning and must represent a decline from a previously higher level of functioning." ${ }^{2}$ An operating definition of POCD has emerged from more than a decade of research by The International Study of Postoperative Cognitive Dysfunction and is characterized by subtle deficits in one or more discrete domains of cognition, e.g., attention, concentration, executive function, verbal memory, visuospatial abstraction, and psychomotor speed. ${ }^{8}$ Finally, emergence from anesthesia in children may often be associated with inappropriate motor behaviour, disorientation, and emotional lability. ${ }^{9}$ This condition lacks the fluctuating course that is characteristic of delirium and would be considered more appropriately as a drug effect. While it is tempting to view delirium, dementia, POCD, and emergence agitation as related conditions, there is little empirical evidence to suggest they share a common mechanism.

\section{Pathophysiology}

Unfortunately, little is known about the actual pathophysiologic mechanism of postoperative delirium, but this mechanism is likely multifactorial. Delirium develops as a direct consequence of precipitating factors in a patient who is at risk. Well-recognized risk factors include advanced age, male sex, dementia, depression, immobility, sensory impairment, dehydration, malnutrition, treatment with multiple psychoactive drugs, and metabolic derangements, to name but a few. ${ }^{3}$ Among surgical patients, the incidence of delirium depends on the type of surgical procedure performed, the drugs administered in the perioperative period, and the presence of infections. Shock, hypoxia, fever, anemia, dehydration, use of physical restraints, use of bladder catheters, pain, and emotional stress are all factors that can precipitate delirium. ${ }^{3}$ The pathogenesis of delirium in these patients results from altered neurotransmission, inflammation, and stress. ${ }^{3}$ A large body of evidence supports a balance between cholinergic and dopaminergic neurotransmitters as a key factor in the development of delirium. ${ }^{10}$ Indeed, drugs with anticholinergic properties can precipitate delirium in certain patients, ${ }^{11}$ and treatment with cholinesterase inhibitors can effectively treat delirium in some circumstances. ${ }^{3}$ An excess of dopamine in certain areas of the brain has also been related to delirium, ${ }^{10}$ and one of the most effective treatment strategies for delirium is the use of antipsychotic agents, which exert their primary therapeutic effect by blocking dopamine receptors. ${ }^{7}$ Inflammatory mediators, such as interleukin-1, interferon, and tumour necrosis 
factor $\alpha$, may contribute to the development of delirium by increasing the permeability of the blood brain barrier, thereby altering neurotransmission. Additionally, the stress response from surgery is known to cause an increase in sympathetic activity and the release of cortisol which may also play a role in the genesis of delirium. ${ }^{3}$

\section{Incidence}

A review of 80 primary studies revealed that delirium develops in $36.8 \%$ (range $0-73.5 \%$ ) of surgical patients. ${ }^{12}$ There appears to be a particularly high risk of postoperative delirium in patients undergoing hip fracture repair (16$44 \%)$ and vascular surgery $(29-39 \%) .{ }^{13}$ While results from individual studies vary, delirium develops most frequently from postoperative day one to day three. ${ }^{7}$ It is likely that most clinicians underestimate the incidence of delirium in their practice. In a study of 797 hospitalized patients over the age of 70, bedside nurses and trained research assistants made 2,721 paired assessments for delirium. Using a validated screening tool, research assistants identified 239 (9\%) instances of delirium in 131 (16\%) patients. Bedside caregivers using clinical acumen alone reported only 46 abnormal evaluations (19\% of those reported by research assistants) involving 40 patients (30\% of those identified by research staff as being delirious). ${ }^{14}$ These findings indicate that clinicians must actively seek delirium if they wish to identify and treat the syndrome in their practice.

\section{Predictors}

Various clinical prediction models for postoperative delirium have been published, some procedure-specific ${ }^{15,16}$ and others more general in scope. ${ }^{17-19}$ A representative riskprediction model designed for an unselected population of non-cardiac surgical patients is detailed in Table $1 .{ }^{18}$ In a recent systematic review assessing the available medical and surgical risk-prediction models, several common themes were identified among the variety of predictor variables reported; the rapidity and severity of the physical insult and the patient's comorbidities appear as the key features predicting delirium following surgery. ${ }^{20}$ Surgery performed on an emergency basis (rapidity of onset) places patients at a uniquely high risk of delirium. A prospective cohort study evaluating predictors of delirium after hip fracture repair $(n=135)$ and total hip arthroplasty ( $n=468)$ identified that patients undergoing emergency surgery remained at an increased risk (risk ratio [RR] 4.04; $95 \%$ confidence interval [CI] 2.69 to 6.18) even after controlling for other risk factors. ${ }^{21}$ Similarly, surgical procedures associated with a greater severity of physical
Table 1 A clinical prediction rule for delirium after elective noncardiac surgery ${ }^{18}$

\begin{tabular}{lll}
\hline Variable & Criteria & Points \\
\hline Cognitive impairment & TICS score $<30$ & 1 \\
Age $\geq 70$ & Yes & 1 \\
Physical impairment & SAS Class IV & 1 \\
& $\quad$ (unable to perform 3 METs) & \\
Laboratory abnormality & Sodium $<130$ & 1 \\
& $\quad$ or $>150 \mathrm{mmol} \cdot \mathrm{L}^{-1}$ & \\
& Potassium $<3.0$ & \\
& $\quad$ or $>6.0 \mathrm{mmol} \cdot \mathrm{L}^{-1}$ & \\
& Glucose $<3.3$ & \\
& or $>16.7 \mathrm{mmol} \cdot \mathrm{L}^{-1}$ & \\
Aortic aneurysm surgery & Yes & 2 \\
Non-cardiac thoracic surgery & Yes & 1 \\
\hline
\end{tabular}

TICS $=$ telephone interview for cognitive status (a score $<30$ indicates minimal cognitive impairment) $;{ }^{49}$ SAS $=$ specific activity scale ${ }^{50}$ METs $=$ metabolic equivalents (Class IV is equivalent to exercise tolerance $\leq 2$ METS); 0 points $=1-2 \%$ incidence of delirium; $1-2$ points $=8-19 \%$ incidence of delirium; $\geq 3$ points $=45$ $55 \%$ incidence of delirium

insult predisposes patients to postoperative delirium. In an observational cohort study of 153 patients undergoing vascular surgery, the rate of delirium in those undergoing aortic surgery $(48.8 \%)$ was more than $50 \%$ greater than the rate in those undergoing non-aortic surgery $(28.8 \%){ }^{22}$ In a study of 764 critically ill patients, an increase in the severity of illness by a single point, as assessed by the APACHE II score, resulted in a $4.9 \%$ relative increase in the odds of delirium. ${ }^{23}$ When compared with non-delirious controls, higher levels of inflammatory cytokines, such as interleukins 6 and 8, were noted among delirious patients following hip fracture repair. ${ }^{24}$ That emergency or complicated surgery predispose to delirium would come as little surprise to the perioperative physician; however, there are a number of patient-specific risk factors that may predict risk. The factors common to most models (factors vary from model to model) are summarized in Table 2, and they are grouped broadly into cognitive, medical, and functional classes. The influence of many factors, including the rapidity and severity of surgical insult, previous cognitive impairment, psychotropic drug use, comorbidity, and poor functional status, suggests that delirium is not a single disease but a common expression of a multifactorial disease process.

\section{Outcomes}

Despite its transient nature, delirium is associated with adverse outcomes both during hospitalization and following discharge. In a prospective cohort study, it was 
Table 2 Patient-specific predictors of delirium ${ }^{20}$

\begin{tabular}{ll}
\hline Predictor & Criteria for increased risk \\
\hline Age & Increasing age \\
ASA physical status & ASA $\geq$ III \\
Sex & Male \\
Cognitive impairment & Dementia \\
& MMSE $<24$ \\
& Poor executive function \\
& Attention deficits \\
Depression & Presence of preoperative depression \\
Smoking & Preoperative smoking \\
Comorbidity & Presence of multiple comorbidities \\
& Risk factors for vascular disease \\
Medications & Three or more medications \\
& Anticholinergic effect \\
Alcohol & Alcohol use \\
Functional status & Inability to perform activities \\
Visual or hearing & of daily living \\
Laboratory abnormalities & Visual or hearing impairment \\
& Anemia (inconsistent) \\
& Hypoalbuminemia \\
& Electrolyte abnormalities \\
& (inconsistent) \\
& Renal insufficiency \\
& An
\end{tabular}

ASA = American Society of Anesthesiologists; $\mathrm{MMSE}=$ MiniMental Status Examination

observed that medical inpatients with a new onset of delirium following hospital admission had lengths of stay approximately eight days longer than control subjects. This increased length of stay, which persisted after adjustment for known covariates, was not present among those patients admitted with a diagnosis of delirium. ${ }^{25}$ A recent metaanalysis evaluating high-quality publications in a mixture of medical and surgical populations identified that delirium was associated with an increased risk of mortality (RR 1.95; $95 \%$ CI 1.51 to 2.52 ), institutionalization following discharge (odds ratio [OR] 2.41; 95\% CI 1.77 to 3.29), and new diagnosis of dementia (OR 12.5; 95\% CI 1.86 to $84.21){ }^{26}$ It is unclear if the relationship between delirium and adverse outcome is causative, if treatment improves outcome, or if delirium is simply a marker for patients experiencing or at risk of experiencing adverse health outcomes. Regardless, the presence of delirium should alert clinicians to a patient "at risk".

\section{Screening tools}

A variety of bedside screening tools are available to assist the clinician in the identification of delirium. In a recent systematic review, ${ }^{27}$ eleven tools were identified for the assessment of delirium, and the Confusion Assessment Method $(\mathrm{CAM})^{28}$ was reported as the best validated and most accurate of the tools reviewed. The CAM operationalizes the DSM-IV definition of delirium by asking the assessor to identify four diagnostic features associated with delirium: 1) acute onset and fluctuating course; 2) inattention; 3) disorganized thinking; and 4) altered level of consciousness. The CAM provides a dichotomous outcome - delirium is either present or absent - based on the presence of features 1 and 2 plus either 3 or 4 . The CAM is accurate at both ruling in and ruling out delirium with a summary positive likelihood ratio (LR) of 7.3 (95\% CI 1.9 to 27 ) and a negative LR of 0.08 (95\% CI 0.03 to 0.21$).{ }^{27} \mathrm{It}$ is noteworthy that the Mini-Mental Status Examination, a screening tool for dementia, was the least accurate of the 11 tools assessed, and it is not recommended for delirium screening. ${ }^{27}$ The CAM, which is available in ten languages and has been modified for use among the ventilatordependent critically ill $^{29}$ (as the CAM-ICU), can be incorporated easily into daily evaluations. Freidman reported that the daily use of the CAM-ICU by their acute pain service added only $2.3 \mathrm{~min}$ to their assessments but identified seven cases of delirium (of eight total) not evident to bedside caregivers. ${ }^{30}$ The foregoing sections hint that older patients undergoing high-risk surgical procedures might benefit from active surveillance for delirium.

\section{Prevention}

The anesthesiologist can play a critical role in identifying elective and emergency patients at highest risk of developing delirium in the perioperative period. Predictive tools to assess this risk have been discussed. Once high-risk patients have been identified, strategies can be put in place to prevent the onset of delirium, to monitor for its development, and to treat it quickly and appropriately should it occur. The following discussion provides a structured approach to delirium prevention and considers perioperative care (the preoperative and postoperative periods) and anesthetic care separately.

\section{Perioperative care}

\section{Preoperative consultation}

In a randomized controlled trial (RCT), ${ }^{31}$ the benefit of proactive geriatric consultation on the incidence of delirium was studied in 126 patients aged $65 \mathrm{yr}$ and older who were admitted for primary surgical repair of a hip fracture. The intervention involved daily consultation with a 
geriatrician, which began at least $24 \mathrm{hr}$ before surgery and continued for the duration of the admission. A protocol was implemented to define supplemental oxygen use, restoration of normal fluid and electrolyte balance, treatment of severe pain, elimination of unnecessary medications, and early mobilization. Control patients received the usual care, which may have included consultation by internal medicine or geriatrics. The cumulative incidence of delirium was $32 \%$ in the proactive geriatric consult group and $50 \%$ in the control group $(P=0.04)$, and the incidence of severe delirium was $12 \%$ in the treatment group and $29 \%$ in the control group $(P=0.02)$. Similar beneficial results were seen in a study of 199 elderly patients with femoral neck fracture $^{32}$ who were randomized postoperatively either to care in a specialized geriatric ward or to care in a conventional orthopedic ward. The patients receiving specialized care experienced a reduction in the incidence (55\% vs 75\%; $P=0.003)$ and duration (5.0 vs 10.2 days; $P=0.009)$ of delirium.

\section{Pharmacologic agents}

Haloperidol, an antipsychotic agent, was compared with placebo for prophylaxis of delirium in an RCT involving 430 patients aged $70 \mathrm{yr}$ and older who were admitted for hip surgery. ${ }^{33}$ Patients were randomized to receive either haloperidol $0.5 \mathrm{mg}$ three times daily or matching placebo up to $72 \mathrm{hr}$ preoperatively, and they were to continue taking the study drug for three days after surgery. All patients in this study received proactive geriatric consultation. The incidence of delirium was similar $(15.1 \% \mathrm{vs}$ $16.5 \%$ ); however, the haloperidol-treated patients experienced a significantly shorter mean duration of delirium (5.4 days $v s 11.8$ days; $P<0.001$ ) and length of hospital stay (17.1 days $v s 22.6$ days; $P<0.001)$ than the placebo patients. Olanzapine is an atypical antipsychotic agent which has lower affinity for histamine, cholinergic muscarinic, and $\alpha$ adrenergic receptors and may be preferred in elderly patients. In a double-blind trial, 495 patients undergoing elective hip and knee surgery were randomized to olanzapine $5 \mathrm{mg}$ immediately before and after surgery or matching placebo. ${ }^{34}$ The olanzapine treatment reduced the incidence of delirium in both hip $(7.6 \%$ vs $30.8 \%$; $P<0.001)$ and knee $(17.7 \%$ vs $47.7 \% ; P<0.001)$ surgeries. While olanzapine-treated patients demonstrated less delirium, there was no difference seen in either the duration or severity of delirium. It is interesting to find such a large discrepancy between the haloperidol study and the olanzapine study in terms of the incidence of delirium in placebo-treated patients ( $16.5 \%$ vs $40.2 \%$, respectively). This result likely reflects the fact that all haloperidol patients received proactive geriatrics consultation, which is known to reduce the rate of perioperative delirium. The
Food and Drug Administration in the United States has issued a black box warning that patients with dementiarelated psychosis treated with atypical antipsychotic medications (like olanzapine) are at an increased risk of death compared with those treated with placebo. This issue should be kept in mind when treating delirium in the demented surgical patient.

Given that a relative deficiency of cholinergic neurotransmitters may play a role in the pathophysiology of delirium, studies have been carried out to determine whether cholinesterase inhibitors reduce postoperative delirium. Donepezil $5 \mathrm{mg}$ once daily was compared with placebo in a double-blind RCT for the prevention and treatment of postoperative delirium in patients undergoing total joint replacement surgery. ${ }^{35}$ Donepezil or placebo was started 14 days before surgery and continued for 14 days after surgery. Neither the incidence of delirium nor the mean duration of delirium was different between groups. In another RCT, ${ }^{36} 33$ patients undergoing elective total hip replacement were randomly assigned to receive either donepezil $5 \mathrm{mg}$ or placebo immediately following surgery and once daily thereafter for a further three days. Delirium occurred in $9.5 \%$ of the patients treated with donepezil and in $35.7 \%$ of the patients treated with placebo $(P=0.08)$; however, these results were not statistically significant because of the small sample size. Based on current evidence, donepezil is not recommended for routine prevention of postoperative delirium.

Anesthetic care

\section{Opioids for analgesia}

It is recognized that opioid analgesics are associated with postoperative delirium. Unfortunately, the vast majority of patients still require opioid analgesia to manage postoperative pain. The choice of opioid used and the associated incidence of delirium has been assessed in a systematic review. ${ }^{37}$ In all studies where meperidine was compared with another opioid, meperidine was associated with a higher incidence of postoperative delirium. In all other comparisons, no differences were found. Meperidine is unique among narcotic analgesics in that it has anticholinergic properties, which likely accounts for its higher potential to cause delirium.

\section{Peripheral nerve blocks for analgesia}

Fascia iliaca compartment block for analgesia before and after hip fracture repair has been advocated as a means of both improving analgesia and reducing opioid exposure. ${ }^{38}$ In a RCT, 219 patients aged $70 \mathrm{yr}$ and older with hip fracture received fascia iliaca compartment block with 
$0.25 \%$ bupivacaine $0.3 \mathrm{~mL} \cdot \mathrm{kg}^{-1}$ or placebo on admission, and this was repeated every day until delirium occurred or until the patient underwent surgery. Active treatment with bupivacaine reduced the risk of delirium from $23.8 \%$ to $10.8 \%$ (RR 0.45 ; $95 \%$ CI 0.23 to 0.87 ).

\section{Gabapentinoids}

Gabapentin and pregabalin have been suggested for acute postoperative pain management. In a small double-blind, placebo-controlled pilot trial, 21 patients undergoing spine surgery were randomized to gabapentin $900 \mathrm{mg}$ orally one to two hours prior to surgery and repeated daily for three days or placebo. ${ }^{39}$ The incidence of postoperative delirium was $42 \%$ in placebo-treated patients and $0 \%$ in gabapentintreated patients, which was significant at a $P=0.045$ level. While these results are certainly dramatic, they will require further investigation in a larger scale RCT.

\section{Type of anesthetic}

Perhaps one of the most common questions about anesthetic care is whether the type of anesthetic has an influence on the rate of postoperative delirium. This question was addressed in an evidence-based clinical update. ${ }^{40} \mathrm{~A}$ total of eight RCTs were found in which patients were randomized to regional anesthesia or general anesthesia, and delirium was used as an outcome measure. In all trials but one, there was no difference found in the rate of postoperative delirium. The trials were conducted in very heterogeneous groups of patients, and there was tremendous variability in intraoperative anesthetic agents used and surgical procedures performed.

\section{Anesthetic drug choice and depth of sedation}

Given that neither general anesthesia nor regional anesthesia offer any advantages over one another, one may then question whether altering the drugs used in the conduct of general anesthesia or whether manipulating the level of sedation given with regional anesthesia may have an effect on rates of postoperative delirium. These questions have been addressed in three separate trials. Choice of volatile or propofol-based anesthesia was evaluated in a study of 50 elderly patients undergoing long-duration laparoscopeassisted surgery. ${ }^{41}$ Participants were assigned randomly to sevoflurane or propofol for induction and maintenance of anesthesia. While median Delirium Rating Scale scores were higher on postoperative days two $(P=0.007)$ and three $(P=0.002)$, individual cases of delirium (four cases vs zero cases; $P=$ reported as NS) were no greater in those
Table 3 Suggested strategies that may help to prevent postoperative delirium

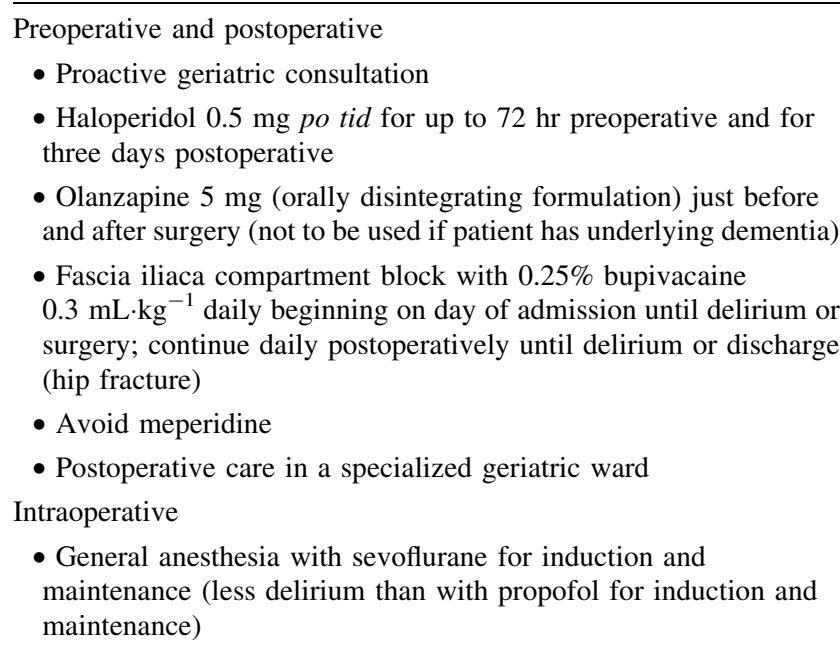

receiving propofol. Similarly, use of nitrous oxide to supplement a variety of volatile inhalational anesthetics bore no influence on delirium in 288 elderly patients undergoing non-cardiac surgery. ${ }^{42}$ Rates of delirium were similar in those randomly assigned to nitrous oxide or to air oxygen supplementation (41.9\% vs 43.8\%, respectively; $P=0.78$ ). Finally, a double-blind $\mathrm{RCT}^{43}$ examined whether depth of sedation with propofol altered rates of delirium in elderly patients undergoing hip fracture repair under spinal anesthesia. A light level of sedation corresponded to a bispectral index (BIS) value of 80 or higher, while a deep level of sedation corresponded to a BIS value of approximately 50 . Patients receiving deep sedation experienced both an increased rate $(40 \%$ vs $19 \% ; P=0.02)$ and duration (1.4 vs 0.5 days; $P=0.01)$ of delirium when compared with the group receiving light sedation. The effect of sedation on rates of delirium was still observed in subgroups of patients with and without baseline cognitive impairment. Prevention strategies are summarized in Table 3.

\section{Treatment of established delirium}

The first and most important step in the management of delirium is to treat and remove potentially reversible precipitating factors. Without addressing these factors, the delirium will persist and potentially worsen. The next step is to treat the delirium. The vast majority of clinical trials that have been conducted in the treatment of postoperative delirium have included antipsychotic agents. Several systematic reviews ${ }^{44-48}$ have been carried out to determine if any significant differences exist between the first 
generation antipsychotics (e.g., haloperidol) and the newer second generation antipsychotics (e.g., olanzapine, risperidone). All systematic reviews have yielded similar conclusions. Antipsychotics, whether first or second generation, are effective for treatment of postoperative delirium, and there does not appear to be any clinically significant difference between individual drugs in terms of efficacy rates. It should be noted, however, that the vast majority of studies were small and were not powered to detect significant differences between different drugs. While the efficacy of these drugs appears to be similar, they appear to differ in their side effect profiles. In general, second generation agents are associated with fewer extrapyramidal effects compared with first generation antipsychotics, but they can cause sedation, which is often seen with olanzapine in particular. Also, second generation agents should be used with caution in elderly patients with dementia as use of these drugs in this patient population has been associated with an increased risk of stroke and death. Risperidone may be better tolerated than olanzapine given that it has less antihistaminic and anticholinergic activity. Antipsychotic dosage recommendations published by the American Psychiatric Association (Practice Guideline for the Treatment of Patients with Delirium) and dosages used effectively in clinical trials can be found in Table 4.

Benzodiazepines have been studied for treatment of delirium, but they are of no benefit in the management of delirium in the postoperative patient and they cause sedation. Therefore, in general, they should be avoided unless there is a specific clinical indication, such as delirium associated with alcohol or benzodiazepine withdrawal and delirium related to seizures, or when extrapyramidal side effects or anticholinergic side effects of antipsychotic medications may worsen a patient's condition. Treatment strategies are summarized in Table 4.

Table 4 Treatment options for delirium

Search for and correct all causes of delirium

First generation antipsychotic

- Haloperidol 1-2 mg po Q4H prn

- Haloperidol $0.25-0.5 \mathrm{mg}$ po Q4H prn for elderly patient

Second generation antipsychotic

- Olanzapine 2.5-5 mg po daily in single or divided doses (cut dose by $50 \%$ in frail elderly)

- Risperidone 0.5-1 mg po daily in single or divided doses (cut dose by $50 \%$ in frail elderly)

Other

- Midazolam/lorazepam - for delirium associated with benzodiazepine withdrawal, alcohol withdrawal, or delirium related to seizures

\section{Conclusion}

Delirium is a common condition that occurs in the perioperative period. Delirium must not be confused with POCD. While POCD is a condition that affects global cognitive function for several months and possibly years after surgery and anesthesia, a diagnosis of POCD requires detailed neuropsychological testing. Delirium, on the other hand, can be diagnosed at the bedside with easily used tools. Delirium is by definition a condition with a fluctuating course, and therefore it can be missed. Hence, the attending anesthesiologist must be vigilant in the search for delirium, especially in the patient who is at high risk. While a number of interventions can be undertaken to prevent and treat delirium, the primary focus should be on prevention strategies as these appear to be most effective in overall management. To look after these patients in the most effective manner, it is critical that anesthesiologists work with other physicians (e.g., internists, geriatricians) and health care professionals experienced in the care of elderly patients.

\section{Clinical case scenario}

D.B. is a 79-yr-old woman who has been booked to have an elective total hip arthroplasty because of worsening osteoarthritis and chronic pain. Her medical history includes type II diabetes mellitus, hypertension, and stable coronary artery disease. She has early Alzheimer's dementia but manages most activities with the support of her daughter with whom she lives. She is taking the following medications: donepezil, glyburide, metformin, hydrochlorothiazide, metoprolol, atorvastatin, enalapril, and long-acting oxycodone. Testing done in the pre-admission unit reveals normal electrolytes, creatinine $120 \mu \mathrm{mol} \cdot \mathrm{L}^{-1}$, random glucose of $17.5 \mathrm{mmol}$. $\mathrm{L}^{-1}$, and a first-degree atrioventricular (AV) block on electrocardiogram. International normalized ratio (INR) and chest $x$-ray are normal.

\section{Instructions for completing the continuing professional development (CPD) module:}

1. Read the current article and the references indicated in bold.

2. Go to: https://www.cpass2.umontreal.ca/selfassessment program/ and select the current module (Postoperative delirium: risk factors and management).

3. Answer the multiple choice questions regarding the case scenario. 
4. Once you have entered all of your answers, you will have access to experts' explanations for all the possible choices.

5. Participants may claim up to four hours of CPD, for a total of 12 credits under Section 3 of the CPD program of the Royal College of Physicians and Surgeons of Canada.

\section{Delirium postopératoire: facteurs de risque et prise en charge}

\begin{abstract}
Résumé
Objectif Le delirium postopératoire reste souvent non diagnostiqué et, par conséquent, non traité. L'objectif de ce module de formation professionnelle continue est d'identifier les patients à haut risque de survenue d'un delirium après une chirurgie non cardiaque et de fournir des outils pour contribuer au diagnostic de delirium au chevet du patient. Des stratégies optimales de prévention et de traitement sont recommandées.
\end{abstract}

Constatations principales Le delirium est caractérisé par une survenue brutale et une évolution fluctuante, une inattention, une pensée désorganisée et un niveau de conscience altérée; jusqu'à $40 \%$ des patients dans la période périopératoire en sont atteints. La physiopathologie du delirium est multifactorielle, mais on pense qu'elle est liée à l'inflammation, à une altération de la neurotransmission et au stress chez un patient venant de subir une chirurgie. L'acétylcholine et la dopamine semblent jouer un rôle significatif. Le risque d'une évolution défavorable, dont un séjour prolongé à l'hôpital ou un décès, est augmenté chez. les patients atteints d'un delirium. Des facteurs liés au patient et à la chirurgie jouent un rôle significatif pour prédire quels patients risquent de présenter secondairement un delirium. La prévention est beaucoup plus efficace que le traitement dans la prise en charge du delirium. Les stratégies de prévention les plus efficaces incluent une évaluation gériatrique proactive, des soins dans les services de chirurgie gériatrique, ainsi que l'administration à but prophylactique de faibles doses d'antipsychotiques. Du point de vue de l'anesthésiste, l'expérience acquise avec certaines populations chirurgicales serait en faveur de l'utilisation des techniques d'anesthésie régionale et de sédation minimale. En cas d'apparition d'un delirium, un traitement par antipsychotique à faible dose par voie orale semble le plus efficace.

Conclusions Le delirium est une pathologie grave qui doit être reconnue précocement et traitée sans retard afin de minimiser le risque de conséquences delétères. Pour instituer des stratégies de prévention et traiter cet état de façon efficace quand il apparait, l'anesthésiologiste doit être vigilant dans l'identification des patients à risque et le dépistage de ce trouble.

\section{Objectifs de ce module de formation professionnelle continue (FPC):}

Après avoir lu ce module, le lecteur devrait être en mesure de:

1. Définir un delirium dans le contexte d'autres modifications cognitives après une chirurgie non cardiaque.

2. Connaître l'incidence et les évolutions indésirables associées au delirium.

3. Énumérer les facteurs prédisposants et déclenchants d'un delirium postopératoire, et identifier les patients à risque.

4. Expliquer les mécanismes physiopathologiques sous-jacents que l'on pense impliqués dans le déclenchement du delirium.

5. Formuler un plan anesthésique qui minimise le risque d'apparition d'un delirium postopératoire.

6. Concevoir un plan de prise en charge pour traiter le delirium postopératoire le plus efficacement possible, tout en minimisant les effets indésirables du traitement.

Comme d'autres nations occidentales, la population du Canada vieillit rapidement. Au cours des 50 dernières années, le pourcentage de Canadiens âgés de plus de 65 ans est passé de 7,7 \% à 13,7\%. ${ }^{\text {A }}$ Statistiques Canada estime que le pourcentage de séniors doublera encore d'ici 2036 et représentera entre $23 \%$ et $25 \%$ de la population canadienne. ${ }^{\mathrm{B}} \mathrm{Ce}$ changement démographique rapide aura un impact direct sur les anesthésiologistes et les hôpitaux, car on estime que, chaque année, une personne sur trois de plus de 65 ans subira une anesthésie. ${ }^{1}$ Malheureusement, un grand nombre de ces événements chirurgicaux sera compliqué par des troubles des fonctions cognitives.

Le delirium est une altération transitoire et fluctuante de la conscience, de l'attention, de la cognition et de la perception. ${ }^{2}$ Bien qu'un delirium puisse survenir chez des patients de tous âges, il s'agit d'une complication particulièrement fréquente de l'anesthésie et de la chirurgie chez les sujets âgés. Des estimations récentes suggèrent que le traitement d'un delirium coûte 2500 dollars (US) supplémentaires en frais de séjour pour les patients âgés de plus de 65 ans, représentant chaque année une facture globale d'environ 6,9 milliards de dollars US pour

\footnotetext{
$\overline{\mathrm{A}} \mathrm{http}: / / \mathrm{www} 12$. statcan.ca/census-recensement/2006/as-sa/97-551/ table/t1-eng.cfm (accessed September 2011).

B http://www.statcan.gc.ca/daily-quotidien/100526/dq100526b-eng. htm (accessed September 2011).
} 
Medicare. ${ }^{3}$ Dans cette perspective, la prévention et le traitement du delirium doivent être considérés comme des priorités pour les patients, comme pour les médecins et les hôpitaux. Ce module aidera les spécialistes en médecine périopératoire à identifier les patients à risque de delirium et proposera des stratégies pour sa prévention et son traitement. Bien que ce sujet ait été étudié récemment, ${ }^{4}$ cet article s'intéressera plus spécifiquement à la physiopathologie, l'incidence et l'évolution, ainsi qu'aux interventions périopératoires spécifiques pour lesquelles on a démontré une action préventive sur le delirium postopératoire.

\section{Définition}

Selon le Manuel diagnostique et statistique des troubles mentaux (DSM-IV), un delirium survenant chez les patients en médecine ou en chirurgie est défini par trois critères: $^{2}$ «A) Un trouble de la conscience (c'est-à-dire, une baisse de contact clair avec l'environnement) avec une capacité réduite à concentrer son attention, la maintenir ou la détourner; B) Une modification de la cognition (comme un déficit mnésique, une désorientation, un trouble du langage) ou l'apparition d'un trouble de la perception; et C) Le trouble évolue sur une courte période (habituellement quelques heures à quelques jours) et tend à fluctuer au cours de la journée. ${ }^{2}$ » Alors que de nombreux cliniciens associent le delirium à un comportement hyperactif (par exemple, agitation, arrachage des perfusions, coups), des sous-types hypoactifs ou à motricité mixte ont également été décrits. ${ }^{5}$ Un delirium hypoactif, caractérisé par « ...une baisse de la vigilance, un discours ralenti ou rare, une léthargie, des mouvements lents, un regard fixe et de l'apathie ${ }^{5}$ peut être présent chez plus de $40 \%$ des patients âgés délirants. ${ }^{6}$

Il faut distinguer le delirium des autres troubles cognitifs, ${ }^{7}$ tels que la démence, les troubles cognitifs dysfonctionnels postopératoires et le delirium à l'émergence de l'anesthésie. Le DSM-IV définit la démence comme de «multiples déficits cognitifs incluant un trouble de la mémoire et au moins l'un des troubles cognitifs suivants: aphasie, apraxie, agnosie ou un trouble des fonctions exécutives. Les déficits cognitifs doivent être suffisamment sévères pour entraîner une gêne dans l'activité professionnelle ou le fonctionnement social et ils doivent représenter un déclin par rapport à un niveau supérieur de fonctionnement observé auparavant. " ${ }^{2}$ Une définition opérationnelle des troubles cognitifs dysfonctionnels postopératoires a été obtenue après plus d'une décennie de recherche de l'étude internationale qui y a été consacrée (The International Study of Postoperative Cognitive Dysfunction) et se caractérise par des déficits subtils dans un ou plusieurs domaines discrets de la cognition, par exemple, l'attention, la concentration, les fonctions exécutives, la mémoire verbale, l'abstraction visuospatiale et la vitesse psychomotrice. $^{8}$ Enfin, l'émergence de l'anesthésie chez les enfants peut être souvent associée à un comportement moteur inapproprié, une désorientation et une labilité émotionnelle. ${ }^{9}$ Cette maladie ne présente pas l'évolution fluctuante qui est caractéristique du delirium et serait considérée, de façon plus logique, comme un effet secondaire des médicaments. Bien qu'il soit tentant de penser que le delirium, la démence, les troubles cognitifs dysfonctionnels postopératoires et l'agitation du réveil sont des troubles apparentés, il existe peu de preuves empiriques pour suggérer qu'ils partagent un mécanisme commun.

\section{Physiopathologie}

On ne sait malheureusement que peu de choses sur le véritable mécanisme physiopathologique du delirium postopératoire, mais il est probablement multifactoriel. Le delirium apparaît comme une conséquence directe de facteurs précipitants chez un patient à risque. Les facteurs de risque bien identifiés sont, pour n'en nommer que quelques-uns: un âge avancé, le sexe masculin, la démence, la dépression, l'immobilité, un trouble sensoriel, une déshydratation, malnutrition, un traitement par de multiples médicaments psychoactifs et des désordres métaboliques. ${ }^{3}$ Chez les patients de chirurgie, l'incidence du delirium dépend du type d'intervention réalisée, des médicaments administrés au cours de la période périopératoire et de l'existence d'une infection. Un choc, une hypoxie, de la fièvre, une anémie, la déshydratation, l'utilisation de moyens de contention physique, l'utilisation d'une sonde vésicale, la douleur et le stress émotionnel sont autant de facteurs qui peuvent précipiter la survenue d'un delirium. ${ }^{3}$ Chez ces patients, la pathogénie du delirium résulte d'une perturbation de la neurotransmission, d'une inflammation et du stress. ${ }^{3}$ Un grand nombre de données probantes montre que l'équilibre entre les neurotransmetteurs cholinergiques et dopaminergiques est un facteur essentiel pour l'apparition d'un delirium. ${ }^{10}$ De fait, des médicaments ayant des propriétés anticholinergiques peuvent précipiter la survenue d'un delirium chez certains patients, ${ }^{11}$ tandis qu'un traitement par des inhibiteurs de la cholinestérase peut, dans certaines circonstances, traiter efficacement un delirium. ${ }^{3}$ L'excès de dopamine dans certaines régions du cerveau a été également associé au delirium ${ }^{10}$ et l'une des stratégies thérapeutiques les plus efficaces repose sur l'utilisation de médicaments antipsychotiques dont le principal effet thérapeutique est obtenu par un blocage des récepteurs de la dopamine. ${ }^{7}$ Les médiateurs de 
l'inflammation, comme l'interleukine-1, l'interféron, et le facteur de nécrose tumorale $\alpha$, peuvent contribuer à la survenue d'un delirium en augmentant la perméabilité de la barrière hématoencéphalique, ce qui aboutit à une altération de la neurotransmission. De plus, la réponse au stress chirurgical est connue pour provoquer une augmentation de l'activité sympathique et une libération de cortisol, ce qui peut jouer aussi un rôle dans la genèse d'un delirium. $^{3}$

\section{Incidence}

L'analyse de 80 études originales a révélé qu'un delirium survient chez $36,8 \%(0 \%-73,5 \%)$ des patients de chirurgie. $^{12}$ Il semble exister un risque particulièrement élevé de delirium postopératoire chez les patients subissant une intervention pour fracture de la hanche $(16 \%$ - $44 \%)$ et pour chirurgie vasculaire $(29 \%-39 \%) .{ }^{13}$ Bien que les résultats de chaque étude soient variables, le delirium apparaît le plus souvent du premier au troisième jour postopératoire. ${ }^{7}$ Il est probable que la plupart des cliniciens sous-estiment en pratique l'incidence du delirium. Dans une étude portant sur plus de 797 patients hospitalisés âgés de plus de 70 ans, des infirmières soignantes et des assistants de recherche spécialement formés ont chacun fait 2721 évaluations de delirium. Utilisant un outil de dépistage validé, les assistants de recherche ont identifié $239(9 \%)$ cas de delirium chez 131 (16\%) patients. Les soignants, ne se fiant qu'à leurs observations cliniques, n'ont signalé que 46 évaluations anormales (19\% de celles signalées par les assistants de recherche) chez 40 patients (30\% des patients identifiés comme atteints de delirium par le personnel de recherche). ${ }^{14}$ Ces résultats indiquent que les cliniciens doivent rechercher activement un delirium s'ils souhaitent identifier et traiter le syndrome.

\section{Éléments prédictifs}

Différents modèles de prédiction clinique du delirium postopératoire ont été publiés: certains sont spécifiques à une intervention ${ }^{15,16}$ et d'autres ont une portée plus générale. ${ }^{17-19}$ Le tableau 1 présente de façon détaillée un modèle représentatif de prédiction du risque conçu pour une population non sélectionnée de patients subissant une chirurgie non cardiaque. ${ }^{18}$ Dans une synthèse systématique récente évaluant les modèles de prédiction du risque médical et chirurgical, plusieurs thèmes communs ont été identifiés parmi les différentes variables prédictives décrites; la rapidité et la gravité de la lésion physique, ainsi que les comorbidités du patient semblent être les caractéristiques essentielles pour prédire la survenue d'un
Tableau 1 Une règle de prédiction clinique du delirium après chirurgie programmée non cardiaque ${ }^{18}$

\begin{tabular}{|c|c|c|}
\hline Variable & Critères & Points \\
\hline Trouble cognitif & Score TICS $<30$ & 1 \\
\hline Âge $\geq 70$ ans & Oui & 1 \\
\hline Trouble physique & $\begin{array}{l}\text { Classe IV sur l'échelle } \\
\text { SAS (incapable } \\
\text { d'effectuer } 3 \text { METs) }\end{array}$ & 1 \\
\hline Anomalie biologique & $\begin{array}{l}\text { Sodium }<130 \\
\quad \text { ou }>150 \mathrm{mmol} \cdot \mathrm{L}^{-1} \\
\text { Potassium }<3,0 \\
\quad \text { ou }>6,0 \mathrm{mmol} \cdot \mathrm{L}^{-1} \\
\text { Glucose }<3,3 \\
\quad \text { ou }>16,7 \mathrm{mmol} \cdot \mathrm{L}^{-1}\end{array}$ & 1 \\
\hline $\begin{array}{l}\text { Chirurgie pour anévrysme de } \\
\text { l'aorte abdominale }\end{array}$ & Oui & 2 \\
\hline $\begin{array}{l}\text { Chirurgie thoracique non } \\
\text { cardiaque }\end{array}$ & Oui & 1 \\
\hline
\end{tabular}

TICS $=$ entretien téléphonique pour la détermination du statut cognitif (un score $<30$ indique un trouble cognitif mineur); ${ }^{49}$ SAS = échelle d'activités spécifiques ${ }^{50}$ MET = équivalents métaboliques d'activité (la classe IV correspond à une tolérance à l'activité physique $\leq 2$ METs); 0 point $=1$ à $2 \%$ d'incidence de delirium; $1-2$ points $=8$ à $19 \%$ d'incidence de delirium; $\geq 3$ points $=45$ à $55 \%$ d'incidence de delirium

delirium après l'intervention chirurgicale. ${ }^{20}$ Une chirurgie réalisée en urgence (rapidité d'apparition) expose les patients un risque particulièrement élevé de delirium. Une étude de cohorte prospective évaluant les facteurs prédictifs de delirium après réparation d'une fracture de la hanche $(n=135)$ et arthroplastie totale de hanche $(n=468)$ a identifié que les patients subissant une chirurgie en urgence présentaient un risque augmenté (rapport de risque [RR] 4,04; intervalle de confiance à $95 \%$ [IC] 2,69 - 6,18) même après avoir contrôlé les autres facteurs de risque. ${ }^{21}$ De même, les interventions chirurgicales associées à des lésions physiques graves prédisposent les patients à un delirium postopératoire. Dans une étude de cohorte observationnelle de 153 patients subissant une chirurgie vasculaire, le taux de delirium chez les patients subissant une chirurgie de l'aorte $(48,8 \%)$ a été supérieur de plus de $50 \%$ au taux observé chez les patients subissant d'autres types de chirurgie $(28,8 \%) .{ }^{22}$ Dans une étude sur 764 patients dans un état critique, une augmentation d'un seul point de la gravité de la maladie (score APACHE II) a abouti à une augmentation relative de $4,9 \%$ du risque de delirium. ${ }^{23}$ Quand on les a comparés à des patients non atteints de delirium, des taux plus élevés de cytokines inflammatoires (interleukine 6 et interleukine 8, par exemple) ont été constatés chez les patients avec delirium après réparation d'une fracture de hanche. ${ }^{24} \mathrm{Le}$ fait qu'une chirurgie urgente ou compliquée prédispose au delirium ne constitue pas réellement une surprise pour le 
Tableau 2 Éléments prédictifs de delirium propres aux patients ${ }^{20}$

\begin{tabular}{|c|c|}
\hline Élément prédictif & Critères d'aggravation du risque \\
\hline Âge & Âge avancé \\
\hline Statut physique ASA & $\mathrm{ASA} \geq \mathrm{III}$ \\
\hline Sexe & Masculin \\
\hline \multirow[t]{4}{*}{ Trouble cognitif } & Démence \\
\hline & MMSE < 24 \\
\hline & Mauvaise fonction exécutive \\
\hline & Déficits de l'attention \\
\hline Dépression & Existence d'une dépression préopératoire \\
\hline Tabagisme & Tabagisme en préopératoire \\
\hline \multirow[t]{2}{*}{ Comorbidités } & Existence de multiples comorbidités \\
\hline & Facteurs de risque de maladie vasculaire \\
\hline \multirow[t]{2}{*}{ Médicaments } & Trois médicaments ou plus \\
\hline & Effet anticholinergique \\
\hline Alcool & Consommation d'alcool \\
\hline Statut fonctionnel & $\begin{array}{l}\text { Impossibilité d'effectuer les activités de } \\
\text { la vie quotidienne }\end{array}$ \\
\hline Vision ou audition & Trouble de la vision ou de l'audition \\
\hline \multirow{4}{*}{$\begin{array}{l}\text { Anomalies des examens de } \\
\text { laboratoire }\end{array}$} & Anémie (inconstante) \\
\hline & Hypoalbuminémie \\
\hline & $\begin{array}{l}\text { Anomalies des électrolytes } \\
\quad \text { (inconstantes) }\end{array}$ \\
\hline & Insuffisance rénale \\
\hline
\end{tabular}

$\mathrm{ASA}=$ American Society of Anesthesiologists; $\mathrm{MMSE}=$ MiniMental Status Examination

spécialiste en médecine périopératoire; il y a toutefois un certain nombre de facteurs de risque propres au patient qui peuvent prédire le risque. Les facteurs communs à la plupart des modèles (les facteurs sont variables d'un modèle à un autre) sont résumés dans le Tableau 2, et ils sont regroupés globalement en trois catégories: facteurs cognitifs, médicaux et fonctionnels. L'influence de nombreux facteurs, y compris la rapidité et la gravité de la lésion chirurgicale, l'existence d'un trouble cognitif antérieur, l'utilisation des médicaments psychotropes, une comorbidité et un mauvais statut fonctionnel, suggère que le delirium n'est pas une maladie unique, mais l'expression commune d'un processus pathologique multifactoriel.

\section{Évolution}

En dépit de sa nature transitoire, le delirium est associé à des évolutions variables, à la fois au cours de l'hospitalisation et après le congé de l'hôpital. Il a été observé dans une étude prospective de cohorte que la durée de séjour des patients admis dans une unité de soins médicaux pour lesquels un nouvel épisode de delirium est survenu pendant l'hospitalisation était plus longue d'environ huit jours par rapport aux patients témoins. Cet allongement de la durée de séjour, qui a persisté après ajustement pour les covariables connues, n'a pas été retrouvé chez les patients hospitalisés pour un diagnostic de delirium. ${ }^{25}$ Une métaanalyse récente évaluant des articles de grande qualité sur des populations mixtes de patients en médecine et en chirurgie a identifié que le delirium était associé à une augmentation du risque de mortalité (RR: 1,95; IC à 95\%: 1,51 - 2,52), d'institutionnalisation après la sortie de l'hôpital (rapport de cotes [RC]: 2,41; IC à $95 \%$ : $1,77-3,29)$, et de nouveaux diagnostics de démence (RC: 12,5; IC à $95 \%$ : $1,86-84,21){ }^{26}$ Il n'est pas certain qu'il y a une relation causale entre le delirium et l'évolution défavorable, ni que le traitement améliore l'évolution; il n'est pas non plus possible de dire s'il le delirium est un simple marqueur chez les patients éprouvant ou à risque d'éprouver une évolution défavorable de leur santé. Néanmoins, l'existence d'un delirium doit alerter les cliniciens sur le fait que le patient est « à risque ».

\section{Outil de dépistage}

Il existe différents outils de dépistage utilisables au chevet du patient pour aider le clinicien à identifier un delirium. Onze outils pour l'évaluation d'un delirium ont été identifiés dans une synthèse systématique récente ${ }^{27}$ et la CAM (Confusion Assessment Method, ou méthode d'évaluation de la confusion $)^{28}$ a été jugée la mieux validée et la plus précise parmi les outils étudiés. La CAM prend en compte la définition du delirium telle qu'elle apparaît dans le DSM-IV en demandant à l'évaluateur d'identifier quatre caractéristiques diagnostiques associées au delirium: 1) Début brutal et évolution fluctuante; 2) inattention; 3) pensée désorganisée; et 4) niveau de conscience altéré. La CAM fournit une conclusion sous forme d'alternative: le delirium est présent ou le delirium est absent, en fonction de l'existence des caractéristiques 1 et 2, plus 3 ou 4 . Globalement, la CAM est exacte pour affirmer ou infirmer l'existence d'un delirium avec un rapport de vraisemblance positive de 7,3 (IC à 95\%: 1,9 - 27) et un rapport de vraisemblance négative de 0,08 (IC à $95 \%$ : $0,03-0,21){ }^{27}$ Il est intéressant de noter que le MMSE (Mini-Mental Status Examination), qui est un outil de dépistage de la démence, a été le moins précis des 11 outils évalués et qu'il n'est pas recommandé pour le dépistage du delirium.$^{27} \mathrm{La}$ CAM, disponible en dix langues et modifié pour pouvoir être utilisé auprès de patients dans un état critique et sous ventilateur $^{29}$ (sous le nom de CAM-ICU), peut être facilement inclus dans des évaluations quotidiennes. Freidman a signalé que l'utilisation quotidienne du CAM-ICU par leur service de douleur aiguë n'a allongé 
leurs évaluations que de 2,3 minutes, mais a permis d'identifier sept cas de delirium (sur un total de huit) qui ne semblaient pas évidents aux soignants. ${ }^{30} \mathrm{Ce}$ qui précède indique que les patients plus âgés subissant des interventions chirurgicales à haut risque devraient profiter d'une surveillance active à la recherche de delirium.

\section{Prévention}

L'anesthésiologiste peut jouer un rôle essentiel dans l'identification des patients vus pour une intervention urgente ou programmée qui présentent un niveau élevé de risque de survenue d'un delirium dans la période périopératoire. Les outils de prédiction pour évaluer ce risque ont été discutés. Une fois les patients à haut risque identifiés, des stratégies peuvent être mises en place pour prévenir la survenue du delirium, pour surveiller son apparition éventuelle et pour le traiter rapidement et de façon appropriée s'il survient. La discussion suivante fournit une approche structurée à la prévention du delirium et envisage séparément les soins périopératoires (les périodes préopératoires et postopératoires) et les soins d'anesthésie.

\section{Soins périopératoires}

\section{Consultation préopératoire}

Au cours d'un essai randomisé contrôlé, ${ }^{31}$ l'intérêt d'une consultation gériatrique proactive sur l'incidence du delirium a été étudié chez 126 patients âgés de 65 ans et plus qui étaient hospitalisés pour la réparation chirurgicale primaire d'une fracture de la hanche. L'intervention a consisté en une consultation quotidienne avec un gériatre qui a commencé au moins 24 heures avant la chirurgie et s'est poursuivie pendant toute la durée de l'hospitalisation. Un protocole a été mis en œuvre pour définir l'utilisation supplémentaire d'oxygène, le retour à un équilibre liquidien et électrolytique normal, le traitement de la douleur sévère, l'élimination des médicaments non nécessaires et la mobilisation précoce. Les patients du groupe témoin ont reçu les soins habituels qui pouvaient inclure une consultation de médecine interne ou de gériatrie. L'incidence cumulée de delirium a été de $32 \%$ dans le groupe bénéficiant d'une consultation gériatrique proactive et de $50 \%$ dans le groupe témoin $(P=0,04)$; l'incidence de delirium sévère a été de $12 \%$ dans le groupe de traitements et de $29 \%$ dans le groupe témoin $(P=0,02)$. Des résultats bénéfiques similaires ont été observés dans une étude portant sur 199 patients âgés ayant une fracture du col fémoral ${ }^{32}$ qui avaient été randomisés en postopératoire pour recevoir des soins dans un service gériatrique spécialisé ou dans un service d'orthopédie conventionnel. Chez les patients recevant des soins spécialisés, il y a eu une réduction de l'incidence $(55 \%$ contre $75 \% ; P=0,003)$ et de la durée $(5,0$ contre 10,2 jours; $P=0,009)$ de delirium.

\section{Agents pharmacologiques}

L'halopéridol, un antipsychotique, a été comparé au placebo pour la prophylaxie du delirium dans une étude randomisée contrôlée incluant 430 patients âgés de 70 ans et plus qui avaient été hospitalisés pour chirurgie de la hanche. ${ }^{33}$ Les patients ont été randomisés pour recevoir le $0,5 \mathrm{mg}$ d'halopéridol trois fois par jour ou les placebos correspondants pendant une durée maximum de 72 heures en préopératoire et ils ont continué à prendre le médicament étudié pendant trois jours après la chirurgie. Tous les patients de cette étude ont bénéficié d'une consultation gériatrique proactive. L'incidence de delirium a été comparable dans les deux groupes $(15,1 \%$ contre $16,5 \%)$; toutefois, les patients traités à l'halopéridol ont connu une durée moyenne du delirium (5,4 jours contre $11,8$ jours; $P<0,001)$ et une durée d'hospitalisation $(17,1$ jours contre 22,6 jours; $P<0,001$ ) significativement plus courtes que les patients ayant reçu le placebo. L'olanzapine est un antipsychotique atypique qui a une moindre affinité pour les récepteurs histaminiques, cholinergiques muscariniques et $\alpha$ adrénergiques; il peut donc être préféré chez les patients âgés. Dans une étude en double insu, 495 patients devant subir une chirurgie programmée de la hanche et du genou ont été randomisé pour recevoir $5 \mathrm{mg}$ d'olanzapine immédiatement avant et après la chirurgie ou le placebo correspondant. ${ }^{34}$ Le traitement à l'olanzapine a réduit l'incidence de delirium dans la chirurgie de la hanche $(7,6 \%$ contre $30,8 \% ; P<0,001)$ et dans celle du genou $(17,7 \%$ contre $47,7 \% ; P<0,001)$. Bien que les patients traités à l'olanzapine aient éprouvé moins de delirium, il n'y a pas eu de différences quant à la durée et à la sévérité du delirium entre les deux groupes. Il est intéressant de constater une telle divergence entre l'étude sur l'halopéridol et celle sur l'olanzapine en termes d'incidence du delirium chez les patients ayant reçu un placebo (respectivement, 16,5\% contre 40,2\%). Ce résultat reflète vraisemblablement le fait que tous les patients de l'étude halopéridol avaient eu une consultation proactive en gériatrie, ce qui est connu pour réduire l'incidence de delirium périopératoire. La Food and Drug Administration des États-Unis émis un avertissement dans un encadré noir pour indiquer que les patients souffrant d'une psychose liée à une démence et traitée par des antipsychotiques atypiques (comme l'olanzapine) présentent un risque accru de décès comparativement aux patients recevant un placebo. On doit garder ce problème à 
l'esprit lors du traitement d'un delirium chez un patient de chirurgie dément.

Étant donné qu'un déficit relatif en neurotransmetteurs cholinergiques peut jouer un rôle dans la physiopathologie du delirium, des études ont été menées pour déterminer si les inhibiteurs de la cholinestérase pouvaient diminuer le delirium postopératoire. Le donepezil $5 \mathrm{mg}$, administré une fois par jour, a été comparé à un placebo dans une étude randomisée contrôlée à double insu pour la prévention et le traitement du delirium postopératoire chez les patients subissant une arthroplastie totale. ${ }^{35}$ Le donepézil ou le placebo était commencé 14 jours avant l'intervention et poursuivi 14 jours après. Ni l'incidence du delirium, ni sa durée moyenne n'ont été différentes entre les deux groupes. Au cours d'une autre étude randomisée contrôlée, ${ }^{36} 33$ patients subissant une arthroplastie totale de hanche ont été randomisés pour recevoir $5 \mathrm{mg}$ de donepézil ou un placebo immédiatement après l'intervention, puis une fois par jour ensuite pendant trois jours supplémentaires. Un delirium est survenu chez 9,5\% des patients traités au donepézil et chez $35,7 \%$ des patients recevant le placebo $(P=0,08)$; toutefois, ces résultats n'ont pas été statistiquement significatifs en raison de la petite taille de l'échantillon. Sur la base des données actuellement disponibles, le donepézil n'est pas recommandé en routine pour la prévention du delirium postopératoire.

Soins anesthésiques

\section{Analgésie aux morphiniques}

Il était admis que certains analgésiques morphiniques sont associés un delirium postopératoire. Malheureusement, la grande majorité des patients nécessite encore une analgésie aux morphiniques pour la prise en charge de la douleur postopératoire. Le choix du morphinique utilisé et l'incidence du delirium qui lui est associée ont fait l'objet d'une évaluation dans une synthèse systématique. ${ }^{37}$ Dans toutes les études au cours desquelles la mépéridine a été comparée à un autre morphinique, la mépéridine a été associée à une plus grande incidence de delirium postopératoire. Aucune différence n'a été trouvée pour toutes les autres comparaisons. La mépéridine est unique parmi les analgésiques morphiniques en raison de ses propriétés anticholinergiques qui sont probablement la cause du risque plus élevé de delirium.

\section{Blocs nerveux périphériques pour l'analgésie}

Il a été proposé qu'un bloc de la loge du fascia iliaca, avant et après réparation d'une fracture de la hanche, était un moyen pour, à la fois, améliorer l'analgésie et réduire l'exposition aux morphiniques. ${ }^{38} \mathrm{Au}$ cours d'un essai clinique randomisé et contrôlé, 219 patients âgés de 70 ans et plus ayant une fracture de la hanche ont reçu un bloc de la loge du fascia iliaca avec $0,3 \mathrm{~mL} \cdot \mathrm{kg}^{-1}$ de bupivacaïne à $0,25 \%$ ou un placebo au moment de leur hospitalisation et cela a été renouvelé chaque jour jusqu'à la survenue d'un delirium ou jusqu'à ce que le patient subisse une chirurgie. Le traitement actif par la bupivacaïne a réduit le risque de delirium de $23,8 \%$ à $10,8 \%$ (RR: 0,45 ; IC à $95 \%$ : 0,23-0,87).

\section{Gabapentinoïdes}

La gabapentine et la prégabaline ont été proposées pour le contrôle de la douleur aiguë postopératoire. Dans un petit essai pilote à double insu, contre placebo, 21 patients subissant une chirurgie du rachis ont été randomisés pour recevoir $900 \mathrm{mg}$ de gabapentine par voie orale, une à deux heures avant l'intervention chirurgicale, puis chaque jour pendant trois jours ou un placebo. ${ }^{39}$ L'incidence de delirium postopératoire a été de $42 \%$ dans le groupe recevant un placebo et de $0 \%$ dans le groupe traité à la gabapentine, ce qui était significatif avec une valeur de $P=0,045$. Bien que ces résultats soient certainement impressionnants, il nécessite néanmoins des études complémentaires avec un essai randomisé de plus grande taille.

\section{Type d'anesthésique}

Sans doute l'une des questions les plus fréquemment posées concernant les soins d'anesthésie est de savoir si le type d'anesthésie a une influence sur l'incidence de delirium postopératoire. Cette question a été abordée dans une mise à jour clinique basée sur des données probantes. ${ }^{40}$ Un total de huit essais randomisés contrôlés ont été trouvés: après randomisation, les patients ont reçu une anesthésie régionale ou une anesthésie générale et la survenue d'un delirium a servi de critère d'évaluation. Dans toutes les études sauf une, il n'y a pas eu de différence dans l'incidence de delirium postopératoire. Les études avaient été menées sur des groupes de patients très hétérogènes et il y a eu d'énormes variations concernant, d'une part, les anesthésiques utilisés au cours de l'intervention et, d'autre part, les interventions chirurgicales pratiquées.

\section{Choix de l'anesthésique et profondeur de la sédation}

Considérant que ni l'anesthésie générale, ni l'anesthésie régionale ne présentent d'avantages l'une par rapport à l'autre, on peut alors se poser la question de savoir si, en changeant les médicaments utilisés au cours de l'anesthésie 
générale ou en manipulant le niveau de sédation administrée avec une anesthésie régionale, il est possible d'agir sur l'incidence de delirium postopératoire. Ces questions ont été abordées dans trois études différentes. La différence entre une anesthésie aux agents volatils et une anesthésie à base de propofol a été évalué dans une étude incluant 50 patients âgés subissant une chirurgie laparoscopique de longue durée. ${ }^{41}$ Après randomisation, les patients ont reçu du sevoflurane ou du propofol pour l'induction et le maintien de l'anesthésie. Bien que les scores médians de l'échelle d'évaluation du delirium (Delirium Rating Scale) aient été plus élevés au cours du deuxième $(P=0,007)$ et du troisième $(P=0,002)$ jour postopératoire, les cas individuels de delirium (4 cas contre 0 cas; $P=\mathrm{NS}$ ) n'ont pas été jugés plus fréquents chez les patients recevant le propofol. De même, l'utilisation de protoxyde d'azote pour compléter différents anesthésiques inhalés volatils n'a eu aucune influence sur le delirium chez 288 patients âgés subissant une chirurgie non cardiaque. ${ }^{42}$ L'incidence de delirium a été comparable chez ceux qui avaient été assignés au hasard à une supplémentation au protoxyde d'azote ou à l'air-oxygène (respectivement, $41,9 \%$ contre $43,8 \% ; P=0,78$ ). Enfin, une étude randomisée à double insu ${ }^{43}$ a étudié si la profondeur de la sédation au propofol modifiait la fréquence de delirium chez les patients âgés subissant une réparation chirurgicale d'une fracture de la hanche sous rachi-anesthésie. Un niveau léger de sédation correspondait à une valeur de l'indice bispectral (BIS) de 80 ou plus, tandis qu'un niveau de sédation profonde correspondait à une valeur du BIS d'environ 50. Les patients recevant une sédation profonde ont éprouvé, à la fois, une plus grande fréquence (40\% contre $19 \% ; P=0,02)$ et une plus longue durée $(1,4$ jour contre 0,5 jour; $P=0,01$ ) de delirium comparativement au groupe recevant une sédation légère. L'effet de la sédation sur l'incidence de delirium était encore observé dans des sous-groupes de patients présentant, ou non, un trouble cognitif avant l'intervention. Les stratégies de prévention sont résumées dans le Tableau 3.

\section{Traitement d'un delirium installé}

La première étape, et plus importante, dans la prise en charge d'un delirium est de traiter et d'éliminer les facteurs favorisants potentiellement réversibles. Sans s'intéresser à ces facteurs, le delirium persistera et risquera de s'aggraver. L'étape suivante consiste à traiter le delirium. La grande majorité des essais cliniques menés sur le traitement du delirium postopératoire ont inclus des antipsychotiques. Plusieurs analyses systématiques ${ }^{44-48}$ ont été réalisées pour déterminer s'il existait des différences significatives entre les antipsychotiques de première
Tableau 3 Stratégies suggérées pouvant contribuer à prévenir le delirium postopératoire

Pré et postopératoire

- Consultation gériatrique proactive

- Halopéridol 0,5 mg per os tid pendant une période pouvant atteindre 72 heures en préopératoire et trois jours en postopératoire

- Olanzapine $5 \mathrm{mg}$ (forme dosifiée orale se désintégrant rapidement) juste avant et après l'opération (à ne pas utiliser chez des patients ayant une démence sous-jacente)

- Bloc de la loge du fascia iliaca à la bupivacaïne $0,25 \%$ $\left(0,3 \mathrm{~mL} \cdot \mathrm{kg}^{-1)}\right.$ chaque jour en commençant le jour de l'admission jusqu'à la survenue d'un delirium ou la chirurgie; continuer chaque jour en postopératoire jusqu'à la survenue d'un delirium ou le congé de l'hôpital (fracture de la hanche)

- Éviter la mépéridine

- Soins postopératoires dans une unité spécialisée de gériatrie

En cours d'intervention

- Anesthésie générale avec le sevoflurane pour l'induction et le maintien de l'anesthésie (moins de delirium qu'avec le propofol pour l'induction et la phase de maintien)

génération (par exemple, l'halopéridol) et les antipsychotiques plus récents de deuxième génération (par exemple, l'olanzapine, la rispéridone). Toutes les analyses systématiques sont parvenues aux mêmes conclusions. Les antipsychotiques, qu'ils soient de première ou de deuxième génération, sont efficaces pour le traitement du delirium postopératoire et il ne semble pas y avoir de différences cliniquement significatives entre les différents médicaments en termes de taux d'efficacité. Il faut cependant noter que, dans leur grande majorité, les études étaient petites il n'y avait pas suffisamment de puissance pour détecter des différences significatives entre plusieurs médicaments. Bien que l'efficacité de ces médicaments paraisse comparable, ils semblent être différents en termes de profils d'effets indésirables. D'une manière générale, les molécules de deuxième génération sont associées à moins d'effets extrapyramidaux que les antipsychotiques de première génération; en revanche, ils peuvent provoquer une sédation comme c'est souvent le cas avec notamment l'olanzapine. Les molécules de deuxième génération doivent aussi être utilisées avec prudence chez les patients âgés souffrant de démence, car l'utilisation de ces médicaments dans cette population a été associée à une augmentation du risque d'accident vasculaire cérébral et de décès. La rispéridone pourrait être mieux tolérée que l'olanzapine considérant qu'elle a une moindre activité antihistaminique et anticholinergique. Les recommandations publiées par l'American Psychiatric Association concernant la posologie des antipsychotiques (Practice Guideline for the Treatment of Patients with Delirium) et les doses efficaces réellement utilisées au cours des études cliniques sont présentées dans le Tableau 4. 
Tableau 4 Options thérapeutiques en présence d'un delirium

Rechercher et corriger toutes les causes de delirium

Antipsychotiques de première génération

- Halopéridol 1-2 mg per os toutes les 4 heures si nécessaire

- Halopéridol 0,25-0,5 mg per os toutes les 4 heures si nécessaire chez le patient âgé

Antipsychotiques de deuxième génération

- Olanzapine 2,5-5 mg per os chaque jour en une ou plusieurs prises (réduire la posologie de $50 \%$ chez les sujets âgés fragiles)

- Rispéridone 0,5-1 mg per os chaque jour en une ou plusieurs doses (réduire la posologie de $50 \%$ chez les sujets âgés fragiles) Autres

- Midazolam/lorazépam - En cas de delirium associé à un syndrome de sevrage des benzodiazépines, ou de l'alcool ou en cas de delirium en rapport avec des crises convulsives.

Les benzodiazépines ont également été étudiées pour le traitement du delirium, mais elles n'offrent pas d'avantages pour la prise en charge du delirium chez un patient en postopératoire; en outre, elles provoquent une sédation. Aussi, d'une manière générale, elles doivent être évitées sauf en cas d'indication clinique spécifique, comme un delirium associé à un syndrome de sevrage de l'alcool ou des benzodiazépines, ou un delirium lié à des crises convulsives, ou encore lorsque les effets indésirables extrapyramidaux ou anticholinergiques des antipsychotiques risquent d'aggraver l'état du patient. Les stratégies thérapeutiques sont résumées dans le Tableau 4.

\section{Conclusion}

Le delirium est un trouble fréquent qui survient dans la période périopératoire. Un delirium ne doit pas être confondu avec les troubles cognitifs dysfonctionnels postopératoires. Tandis que les troubles cognitifs dysfonctionnels postopératoires affectent l'ensemble des fonctions cognitives pendant plusieurs mois et possiblement plusieurs années après une chirurgie et une anesthésie, ce diagnostic nécessite des tests neuropsychologiques approfondis. À l'opposé, le delirium peut-être diagnostiqué au chevet du patient à l'aide d'outils faciles à utiliser. Un delirium est, par définition, un trouble à l'évolution variable et il est donc possible de passer à côté. En conséquence, l'anesthésiologiste responsable doit être vigilant dans sa recherche $\mathrm{du}$ delirium, tout particulièrement chez les patients à haut risque. Bien qu'il soit possible d'entreprendre un certain nombre d'interventions pour prévenir et traiter un delirium, l'attention doit se concentrer sur les stratégies de prévention, car ces dernières semblent les plus efficaces pour une prise en charge globale. Pour s'occuper de ces patients de la façon la plus efficace possible, il est essentiel que les anesthésiologistes travaillent avec d'autres médecins (internistes, gériatres, par exemple) et professionnels de la santé ayant l'expérience des soins aux patients âgés.

\section{Scénario de cas clinique}

D.B. est une femme âgée de 79 ans qui doit subir une arthroplastie totale de hanche programmée en raison d'une aggravation de son arthrose et de la douleur chronique. On trouve dans ses antécédents médicaux: un diabète de type II, une hypertension et une coronaropathie stable. La patiente présente les premiers signes d'une maladie d'Alzheimer, mais elle est en mesure d'assurer la plupart des activités avec l'aide de sa fille chez qui elle vit. Elle prend les médicaments suivants: donepézil, glyburide, metformine, hydrochlorothiazide, métoprolol, atorvastatine, énalapril et oxycodone à longue durée d'action. Les tests réalisés dans l'unité de pré-admission ont montré: électrolytes normaux, créatinine à $120 \mu \mathrm{mol} \cdot \mathrm{L}^{-1}$, glycémie aléatoire à $17,5 \mathrm{mmol} \cdot \mathrm{L}^{-1}$, et un bloc auriculo-ventriculaire (AV) du premier degré à l'électrocardiogramme. L'INR (rapport international normalisé) et la radiographie pulmonaire sont normaux.

Directives pour compléter le module de développement professionnel continu (DPC)

1. Lisez cet article et les références en gras.

2. Allez à: https://www.cpass2.umontreal.ca/selfassess mentprogram/ et sélectionnez le module actuel (Delirium postopératoire: facteurs de risque et prise en charge).

3. Répondez aux questions à choix de réponses concernant le cas clinique.

4. Une fois que vous avez saisi toutes vos réponses, vous aurez accès aux explications d'experts pour tous les choix possibles.

5. Les participants peuvent réclamer un maximum de quatre heures de DPC pour un total de 12 crédits sous la Section $3 \mathrm{du}$ programme de DPC du Collège royal des médecins et chirurgiens du Canada.

\section{Conflict of interest None.}

Funding sources Drs. Chaput and Bryson are supported by The Ottawa Hospital Anesthesia Alternate Funds Association, and they are recipients of research grants from the Canadian Anesthesia Research Fund and Physicians' Services Incorporated for trials evaluating postoperative delirium. Dr. Chaput receives a Distinguished Teacher salary award from the University of Ottawa, and he is the recipient of a research grant from Pfizer Inc. 


\section{References}

1. Clergue F, Auroy $Y$, Pequignot $F$, Jougla E, Lienhart A, Laxenaire $M C$. French survey of anesthesia in 1996. Anesthesiology 1999; 91: 1509-20.

2. American Psychiatric Association. Diagnostic and Statistical Manual of Mental Disorders: DSM IV, Fourth Edition, Text Revision. Washington, DC: American Psychiatric Association, 2000.

3. Inouye SK. Delirium in older persons. N Engl J Med 2006; 354: 1157-65.

4. Rudolph JL, Marcantonio ER. Review articles: postoperative delirium: acute change with long-term implications. Anesth Analg 2011; 112: 1202-11.

5. Liptzin B, Levkoff SE. An empirical study of delirium subtypes. Br J Psychiatry 1992; 161: 843-5.

6. Peterson JF, Pun BT, Dittus RS, et al. Delirium and its motoric subtypes: a study of 614 critically ill patients. J Am Geriatr Soc 2006; 54: 479-84.

7. Deiner S, Silverstein JH. Postoperative delirium and cognitive dysfunction. Br J Anaesth 2009; 103(Suppl 1): i41-6.

8. Rasmussen LS, Larsen K, Houx P, Skovgaard LT, Hanning CD, Moller JT. The assessment of postoperative cognitive function. Acta Anaesthesiol Scand 2001; 45: 275-89.

9. Sikich N, Lerman J. Development and psychometric evaluation of the pediatric anesthesia emergence delirium scale. Anesthesiology 2004 ; 100: 1138-45.

10. Trzepacz $P T$. Is there a final common neural pathway in delirium? Focus on acetylcholine and dopamine. Semin Clin Neuropsychiatry 2000; 5: 132-48.

11. Campbell N, Boustani M, Limbil T, et al. The cognitive impact of anticholinergics: a clinical review. Clin Interv Aging 2009; 4 : 225-33.

12. Dyer CB, Ashton CM, Teasdale TA. Postoperative delirium. A review of 80 primary data-collection studies. Arch Intern Med 1995; 155: 461-5.

13. Dasgupta $M$, Dumbrell AC. Preoperative risk assessment for delirium after noncardiac surgery: a systematic review. J Am Geriatr Soc 2006; 54: 1578-89.

14. Inouye $S K$, Foreman MD, Mion LC, Katz KH, Cooney LM Jr. Nurses' recognition of delirium and its symptoms: comparison of nurse and researcher ratings. Arch Intern Med 2001; 161: 2467-73.

15. Schneider F, Bohner H, Habel U, et al. Risk factors for postoperative delirium in vascular surgery. Gen Hosp Psychiatry 2002; 24: 28-34.

16. Edlund A, Lundstrom M, Lundstrom G, Hedqvist B, Gustafson Y. Clinical profile of delirium in patients treated for femoral neck fractures. Dement Geriatr Cogn Disord 1999; 10: 325-9.

17. Rudolph JL, Jones RN, Rasmussen LS, Silverstein JH, Inouye SK, Marcantonio ER. Independent vascular and cognitive risk factors for postoperative delirium. Am J Med 2007; 120: 807-13.

18. Marcantonio ER, Goldman L, Mangione CM, et al. A clinical prediction rule for delirium after elective noncardiac surgery. JAMA 1994; 271: 134-9.

19. Litaker D, Locala J, Franco K, Bronson DL, Tannous Z. Preoperative risk factors for postoperative delirium. Gen Hosp Psychiatry 2001; 23: 84-9.

20. Noimark D. Predicting the onset of delirium in the postoperative patient. Age Ageing 2009; 38: 368-73.

21. Kalisvaart KJ, Vreeswijk $R$, de Jonghe JF, van der Ploeg $T$, van Gool WA, Eikelenboom P. Risk factors and prediction of postoperative delirium in elderly hip-surgery patients: implementation and validation of a medical risk factor model. J Am Geriatr Soc 2006; 54: 817-22.

22. Bohner H, Hummel TC, Habel U, et al. Predicting delirium after vascular surgery: a model based on pre- and intraoperative data. Ann Surg 2003; 238: 149-56.
23. Ouimet $S$, Kavanagh BP, Gottfried SB, Skrobik $Y$. Incidence, risk factors and consequences of ICU delirium. Intensive Care Med 2007; 33: 66-73.

24. van Munster BC, Korevaar JC, Zwinderman AH, Levi M, Wiersinga WJ, de Rooij SE. Time-course of cytokines during delirium in elderly patients with hip fractures. J Am Geriatr Soc 2008; 56: 1704-9.

25. McCusker J, Cole MG, Dendukuri N, Belzile E. Does delirium increase hospital stay? J Am Geriatr Soc 2003; 51: 1539-46.

26. Witlox J, Eurelings LS, de Jonghe JF, Kalisvaart KJ, Eikelenboom P, van Gool WA. Delirium in elderly patients and the risk of postdischarge mortality, institutionalization, and dementia: a meta-analysis. JAMA 2010; 304: 443-51.

27. Wong CL, Holroyd-Leduc J, Simel DL, Straus SE. Does this patient have delirium?: value of bedside instruments. JAMA 2010; 304: 779-86.

28. Inouye SK, van Dyck CH, Alessi CA, Balkin S, Siegal AP, Horwitz $R I$. Clarifying confusion: the confusion assessment method. A new method for detection of delirium. Ann Intern Med 1990; 113: 941-8.

29. Ely EW, Inouye SK, Bernard GR, et al. Delirium in mechanically ventilated patients: validity and reliability of the confusion assessment method for the intensive care unit (CAM-ICU). JAMA 2001; 286: 2703-10.

30. Friedman Z, Qin J, Berkenstadt H, Katznelson R. The confusion assessment method - a tool for delirium detection by the acute pain service. Pain Pract 2008; 8: 413-6.

31. Marcantonio ER, Flacker JM, Wright RJ, Resnick NM. Reducing delirium after hip fracture: a randomized trial. J Am Geriatr Soc 2001; 49: 516-22.

32. Lundstrom $M$, Olofsson B, Stenvall $M$, et al. Postoperative delirium in old patients with femoral neck fracture: a randomized intervention study. Aging Clin Exp Res 2007; 19: 178-86.

33. Kalisvaart KJ, de Jonghe JF, Bogaards MJ, et al. Haloperidol prophylaxis for elderly hip-surgery patients at risk for delirium: a randomized placebo-controlled study. J Am Geriatr Soc 2005; 53: 1658-66.

34. Larsen KA, Kelly SE, Stern TA, et al. Administration of olanzapine to prevent postoperative delirium in elderly jointreplacement patients: a randomized, controlled trial. Psychosomatics 2010; 51: 409-18.

35. Liptzin B, Laki A, Garb JL, Fingeroth R, Krushell R. Donepezil in the prevention and treatment of post-surgical delirium. Am J Geriatr Psychiatry 2005; 13: 1100-6.

36. Sampson EL, Raven PR, Ndhlovu PN, Vallance A, Garlick N, Watts $J$ et al. A randomized, double blind, placebo-controlled trial of donepezil hydrochloride (Aricept) for reducing the incidence of postoperative delirium after elective total hip replacement. Int J Geriatr Psychiatry 2007; 22: 343-9.

37. Fong HK, Sands LP, Leung JM. The role of postoperative analgesia in delirium and cognitive decline in elderly patients: a systematic review. Anesth Analg 2006; 102: 1255-66.

38. Mouzopoulos $G$, Vasiliadis $G$, Lasanianos $N$, Nikolaras $G$, Morakis E, Kaminaris $M$. Fascia iliaca block prophylaxis for hip fracture patients at risk for delirium: a randomized placebocontrolled study. J Orthopaed Traumatol 2009; 10: 127-33.

39. Leung JM, Sands LP, Rico M, et al. Pilot clinical trial of gabapentin to decrease postoperative delirium in older patients. Neurology 2006; 67: 1251-3.

40. Bryson GL, Wyand A. Evidence-based clinical update: general anesthesia and the risk of delirium and postoperative cognitive dysfunction. Can J Anesth 2006; 53: 669-77.

41. Nishikawa $K$, Nakayama M, Omote $K$, Namiki A. Recovery characteristics and post-operative delirium after long-duration laparoscope-assisted surgery in elderly patients: propofol-based 
vs. sevoflurane-based anesthesia. Acta Anaesthesiol Scand 2004; 48: $162-8$

42. Leung JM, Sands LP, Vaurio LE, Wang Y. Nitrous oxide does not change the incidence of postoperative delirium or cognitive decline in elderly surgical patients. Br J Anaesth 2006; 96: 754-60.

43. Sieber FE, Zakriya KJ, Gottschalk A, et al. Sedation depth during spinal anesthesia and the development of postoperative delirium in elderly patients undergoing hip fracture repair. Mayo Clin Proc 2010; 85: 18-26.

44. Bourne RS, Tahir TA, Borthwick M, Sampson EL. Drug treatment of delirium: past, present and future. J Psychosom Res 2008; 65: 273-82.

45. Rea RS, Battistone S, Fong JJ, Devlin JW. Atypical antipsychotics versus haloperidol for treatment of delirium in acutely ill patients. Pharmacotherapy 2007; 27: 588-94.

46. Lonergan E, Britton AM, Luxenberg J, Wyller T. Antipsychotics for delirium. Cochrane Database Syst Rev 2007; (2): CD005594.

47. Lacasse H, Perreault MM, Williamson DR. Systematic review of antipsychotics for the treatment of hospital-associated delirium in medically or surgically ill patients. Ann Pharmacother 2006; 40: 1966-73.
48. Seitz DP, Gill SS, van Zyl LT. Antipsychotics in the treatment of delirium: a systematic review. J Clin Psychiatry 2007; 68: 11-21.

49. Manly JJ, Schupf N, Stern Y, Brickman AM, Tang MX, Mayeux R. Telephone-based identification of mild cognitive impairment and dementia in a multicultural cohort. Arch Neurol 2011; 68: 607-14.

50. Goldman L, Hashimoto B, Cook EF, Loscalzo A. Comparative reproducibility and validity of systems for assessing cardiovascular functional class: advantages of a new specific activity scale. Circulation 1981; 64: 1227-34.

Conflict of interest None.

\section{Additional reference}

Campbell N, Boustani MA, Ayub A, et al. Pharmacological management of delirium in hospitalized adults - a systematic evidence review. J Gen Intern Med 2009; 24: 848-53. 